\title{
Dexamethasone Increases Superoxide Dismutase Activity in Serum-Free Rat Fetal Lung Organ Cultures
}

\author{
PARMJEET RANDHAWA, MICHAEL HASS, LEE FRANK, AND DONALD MASSARO \\ Pulmonary Research Laboratories, Calvin and Flavia Oak Asthma Research and Treatment Facility, University \\ of Miami School of Medicine, Miami, Florida 33136 and the V.A. Medical Center, Miami, Florida 33125
}

\begin{abstract}
Dexamethasone (Dex) injected intraperitoneally to dams on gestational days 19 through 21 significantly enhances the normal late gestational rise of rat pulmonary superoxide dismutase activity. To study if Dex could act directly on lung cells to increase the activity of superoxide dismutase, rat fetal lung organ cultures were established from 21- or 22-day-old pups and maintained in serum free Waymouth $752 / 1$ medium in $95 \% \mathrm{O}_{2}$ for $72 \mathrm{~h}$ with and without $10 \mathrm{nM}$ Dex in the medium. The cultures increased spontaneously in total superoxide dismutase activity from $17.5 \pm 3.1$ to $33.5 \pm 6.2 \mathrm{U} / \mathrm{mg} \mathrm{DNA}$ during this interval $(+90 \%)$. The presence of $10 \mathrm{nM}$ Dex caused an increase in enzyme activity to $40.1 \pm 9.3 \mathrm{U} / \mathrm{mg} \mathrm{DNA}$ $(+130 \%)$ demonstrating this hormone can act directly on the lung independent of the systemic metabolic consequences of corticosteroid administration. Dex decreased the rate of $\mathrm{Cu}, \mathrm{Zn}$ superoxide dismutase synthesis $(13.5 \pm$ $3.4 \mathrm{nmol}$ Phe incorporated/mg DNA/h control vs $7.2 \pm$ 1.6, Dex) and seemed to also decrease the rate of enzyme degradation. (Pediatr Res 20: 895-898, 1986)
\end{abstract}

\section{Abbreviations}

Dex, dexamethasone

SOD, superoxide dismutase

$\mathrm{Cu}, \mathrm{Zn}$ SOD, copper-zinc superoxide dismutase

$\left[{ }^{3} \mathrm{H}\right] \mathrm{Phe}$, tritiated phenylalanine

Phe, L-phenylalanine

LDH, lactate dehydrogenase

TCA, trichloroacetic acid

The activities of antioxidant enzymes in the lung increase in late gestation in parallel with the development of the lung's surfactant system (1-3). This suggests that in addition to the problems associated with surfactant deficiency, premature birth may expose the newly born to an oxidant stress for which it is inadequately prepared, since extrauterine life imposes on the animal a partial pressure of oxygen that is much higher than is encountered in utero. Dex given to pregnant rats during late gestation accelerates the increase of activity of the antioxidant enzymes (4), but it is not known if the hormone acts directly on lung cells or if its action is mediated by an extrapulmonary mechanism. The purpose of the present work was to determine

Received February 3, 1986; accepted April 30, 1986.

Correspondence and reprint requests to Parmjeet S. Randhawa, M.D., University of Miami School of Medicine, Pulmonary Research R120, P. O. Box 016960, Miami, FL 33101.

Supported by the Calvin and Flavia Oak Asthma Research and Treatment Facility, NIH Grants HL20366 and HL26029, and V.A. Research Funds. whether Dex could act directly on lung cells to increase the activity of SOD, an important component of the lungs antioxidant defense. To achieve this goal we determined the effect of Dex on the activity of SOD in serum-free rat fetal lung organ cultures. We also studied the turnover of $\mathrm{Cu}, \mathrm{Zn} \mathrm{SOD}$ in fetal lung organ culture and examined the effect of Dex on the turnover.

\section{MATERIALS AND METHODS}

Animals. Sprague Dawley rats (Charles River Breeding Laboratories, Wilmington, MA) were used in all experiments. Breeding was effected by keeping together two females and one male overnight. Animals showing the presence of vaginal spermatozoa the next morning (designated as day " 0 ") were presumed pregnant and kept in separate cages. Rats were allowed food (Rodent Laboratory Chow 5001, Ralston-Purine, St. Louis, MO) and water ad libitum and a $12 \mathrm{~h}$ light/12 h dark cycle was maintained.

Organ cultures. On day 21 or 22 (term) of pregnancy pups were delivered by hysterotomy under ether anesthesia, immediately decapitated, and the fetal lungs were dissected out using sterile technique. The tissue was rinsed thrice in Waymouth's MB 752/1 medium (Grand Island Biological Co., Grand Island, NY) and chopped into $1 \mathrm{~mm}^{3}$ pieces with a Mcllwain Tissue Chopper (Brinkmann Instruments, Westbury, NY).

The organ culture technique followed was that of Gross et al. (5). Briefly, $60 \times 15 \mathrm{~mm}$ plastic Petri dishes (Falcon, Oxnard, CA) were scratched with forceps and prewetted with medium. The tissue cubes were placed on the scratched areas and allowed $2 \mathrm{~h}$ to adhere to the plastic. At the completion of this period 2 $\mathrm{ml}$ of medium were pipetted into each dish. The dishes were rocked gently at the rate of three oscillations per minute on a rocker platform (Bellaco, Vineland, $\mathrm{NJ}$ ). A temperature of $37^{\circ} \mathrm{C}$ and gas phase of $95 \% \mathrm{O}_{2}-5 \% \mathrm{CO}_{2}$ was maintained throughout. Relative humidity was in the range $80-90 \%$ as measured by a hygrometer (Cole Parmer, Chicago, IL). Dex (Organon Inc., W. Orange, $\mathrm{NJ}$ ) in a final concentration of $10 \mathrm{nM}$ was added to the medium in some of the dishes. The medium was changed daily and at each change a portion was frozen away at $-70^{\circ} \mathrm{C}$ to be assayed for LDH using a commercially available kit (Sigma, St. Louis, MO).

Histology. Samples of explanted tissue were fixed in $10 \%$ buffered formalin, dehydrated in ascending grades of alcohol, and embedded in Sorvall medium (DuPont, Wilmington, DE). Sections 2-4 $\mu \mathrm{m}$ thick were cut with glass knives, stained with haematoxylin and eosin, and examined by light microscopy.

Chemical measurements. SOD assays were based on the inhibition of xanthine/xanthine oxidase catalyzed reduction of ferricytochrome c using chemicals obtained from Sigma (6). The best method for processing the small tissue samples was determined to be as follows. The explants were scraped off the culture 
dish, pooled, blotted dry, weighed, and transferred to 1-ml cryotubes (Nunc, Reskilde, Denmark). The uncapped cryotubes were placed in a lyophilizer (The Virtis Co., Gardiner, NY) and subjected to lyophilization overnight. Potassium phosphate buffer $5 \mathrm{mM}$, pH 7.8 was added to yield a final volume of 100 $\mu \mathrm{l}$ for every $10 \mathrm{mg}$ wet weight originally taken. The cryotube was centrifuged at $800 \times g$ for $10 \mathrm{~min}$. The supernatant fluid was frozen away at $-20^{\circ} \mathrm{C}$ for SOD assay. The enzyme was found stable for up to 7 days stored in this manner. Soluble proteins in the supernatant material were assayed by the method of Bradford (7) using bovine serum albumin as a standard. The pellet was reconstituted with equal volume of buffer and sonicated for $20 \mathrm{~s}$ under a sonifier cell disruptor with a microprobe attachment (Branson Sonic Power Co., Plainview, IL). The disrupted tissue was analyzed for DNA content using a fluorometric mithramycin binding assay (8). Calf thymus DNA (Sigma) was used as reference standard. All the principal steps in processing viz. lyophilization, weighing, reconstitution in buffer, centrifugation, and sonication were carried out in the same cryotube thereby allowing volumes in the range of $150-750 \mu$ lo be processed with little loss. This permitted measurement of SOD activity in as little as $15 \mathrm{mg}$ of wet tissue. It was necessary to pool lung tissue from up to four litters (32-48 pups) to perform the biochemical, enzymatic, and protein turnover measurements reported herein. The pooled tissue was assigned randomly to Petri dishes exposed to various experimental categories. This minimized interlitter variability and allowed us to use a paired $t$ test analysis to evaluate the effect of specific factors on the activity of SOD in the culture system.

Protein turnover. Measurement of rates of synthesis of protein was based on incorporation of $\left[{ }^{3} \mathrm{H}\right] \mathrm{Phe}$ into trichloroacetic acid precipitable material (general protein) or into $\mathrm{Cu}, \mathrm{Zn}$ SOD. Explants were maintained in culture for $68 \mathrm{~h}$ at which time the medium was replaced with $2 \mathrm{ml}$ fresh medium containing 60 $\mu \mathrm{Ci}$ of $\left[{ }^{3} \mathrm{H}\right] \mathrm{Phe}$ (specific activity $25 \mathrm{Ci} / \mathrm{mol}$, ICN Radio Chemicals, Irvine, CA) and $0.7 \mathrm{mM}$ unlabeled Phe. We chose $0.7 \mathrm{mM}$ Phe because prior studies using neonatal and adult lung slices had shown this concentration results in equilibration of the specific radioactivity of intracellular and extracellular Phe with that of tRNA bound Phe within 15 min (Clerch L, unpublished observations). This equilibration permits the measurement of absolute rates of protein synthesis using the easily measured specific radioactivity of Phe in the medium. Four hours after addition of $\left[{ }^{3} \mathrm{H}\right] \mathrm{Phe}$ the cultures were harvested. The medium was saved for determination of extracellular $\left[{ }^{3} \mathrm{H}\right] \mathrm{Phe}$ specific radioactivity. The explants were washed with cold $0.15 \mathrm{M} \mathrm{NaCl}$ and the tissue disrupted using a Brinkmann polytron run at maximum speed for $45 \mathrm{~s}$. Duplicate $1-\mathrm{ml}$ portions of the broken tissue were saved for extraction of DNA in hot 5\% TCA according to the method of Schneider (9). TCA insoluble material was dissolved in $2 \mathrm{~N} \mathrm{NaOH}$ at $56^{\circ} \mathrm{C}$, placed in aquasol (New England Nuclear, Boston, MA), and radioactivity measured in a Packard Prias PLD liquid scintillation counter using a PPO/POPOP based scintillation fluid $(5 \mathrm{~g}, 2,5$-diphenyloxazole and $0.26 \mathrm{~g} \mathrm{p}$ bis-5-phenyloxazolyl benzene per liter of toluene). Amino acid analysis and $\beta$-counting of individual amino acid fractions revealed that the $\left[{ }^{3} \mathrm{H}\right]$ radiolabel remained with Phe throughout the experiment.

Preparation of rat $\mathrm{Cu}, \mathrm{Zn} \mathrm{SOD}$, labeling with ${ }^{14} \mathrm{C}$ and measurement of the rates of synthesis of $\mathrm{Cu}, \mathrm{Zn}$ SOD were performed as previously described (10). Briefly, the disrupted explant material was centrifuged at $100,000 \times g$ for $1 \mathrm{~h}$. A known amount of $\left[{ }^{14} \mathrm{C}\right] \mathrm{Cu}, \mathrm{Zn}$ SOD was added to the supernatant fraction to allow us to estimate recovery of $\mathrm{Cu}, \mathrm{Zn} \mathrm{SOD}$. $\mathrm{Cu}, \mathrm{Zn}$ SOD was then isolated by immunoprecipitation using polyclonal goat antirat $\mathrm{Cu}, \mathrm{Zn}$ SOD serum (10). The immunoprecipitate was denatured in sodium dodecyl sulfate $\left(100^{\circ} \mathrm{C}\right.$ boiling water bath $\left.\times 10 \mathrm{~min}\right)$ and subjected to polyacrylamide slab gel electrophoresis in a modified Laemelli system consisting of $4 \%$ polyacrylamide as the stacking gel and $11 \%$ polyacrylamide as the separation gel. The gels were subjected to $25 \mathrm{~mA}$ for $4-6 \mathrm{~h}$ after which slices of 2-mm thickness were cut out of the gel. The gels were made soluble by overnight incubation at $56^{\circ} \mathrm{C}$ in Soluene 350 (Packard, Downer's Grove, IL) and counted in scintillation fluid by a dual label $\left[{ }^{3} \mathrm{H} /{ }^{14} \mathrm{C}\right]$ program. We corrected for quenching by the external standard channels ratio technique. The distribution of $\left[{ }^{14} \mathrm{C}\right]$ counts helped to identify the gel slices containing $\mathrm{Cu}, \mathrm{Zn}$ SOD. The $\left[{ }^{3} \mathrm{H}\right]$ counts in these slices multiplied by the recovery factor were used in calculating the incorporation of $\left[{ }^{3} \mathrm{H}\right] \mathrm{Phe}$ into $\mathrm{Cu}, \mathrm{Zn}$ SOD.

To measure the degradation of general protein and $\mathrm{Cu}, \mathrm{Zn}$ SOD, 24-h-old explants were incubated with $60 \mu \mathrm{Ci}$ of $\left[{ }^{3} \mathrm{H}\right] \mathrm{Phe}$ per Petri dish for a further period of $24 \mathrm{~h}$. At this point some of the culture dishes were harvested and processed exactly as in the synthesis experiments in order to obtain the specific radioactivity of general protein and $\mathrm{Cu}, \mathrm{Zn}$ SOD at the completion of the labeling period. We added Phe to a final concentration of 10 $\mathrm{mM}$ to the remaining explants, which were maintained in culture an additional $24 \mathrm{~h}$ before being processed identically to those removed earlier. Previous experiments had shown that at medium Phe concentrations of $2 \mathrm{mM}$ or higher only $0.02 \%$ of $\left[{ }^{3} \mathrm{H}\right]$ Phe derived from protein degradation was reincorporated into protein, and, that concentration of Phe did not itself interfere with the rate of proteolysis (11).

Statistics. Statistical analysis was performed by applying $t$ test for paired samples using a Stats Plus Programme and an Apple IIc computer. $P$ values of $<0.05$ were considered significant.

\section{RESULTS}

Tissue preservation. Examination by light microscopy showed there was good architectural preservation of cultured tissue at 72 h (Fig. 1). We did not detect differences between Dex treated and control explants (not shown). By the 6th day there was loss of alveolar air spaces, nuclear pyknosis, karyorrhexis, and necrosis (not shown). Based on these observations we did not exceed $72 \mathrm{~h}$ in culture in subsequent experiments. During this period, the release of $\mathrm{LDH}$ from the explants into the incubation medium was consistently less than $10 \%$ of the total enzyme content present in tissue and medium at the termination of culture.

Protein and DNA content. The 72-h values for protein, DNA, and protein/DNA in explants incubated without Dex did not exhibit statistically significant differences compared to the " 0 " $\mathrm{h}$ values (Table 1). Explants incubated with $10 \mathrm{mM}$ Dex demonstrated a significant increase above " 0 " $\mathrm{h}$ values in the proteinto-DNA ratio. An $\sim 40 \%$ increase in the mean protein content was observed in the presence of Dex $(p>0.05)$. The concentration of DNA did not change in either the control or Dex group over the 72-h incubation.

SOD activity. The activity of SOD in the explants increased over the 72-h incubation in the absence of Dex (Fig. 2). The addition of Dex to the culture medium resulted in a significantly greater increase of explant SOD activity when the activity was expressed per $g$ of wet tissue, or per mg of DNA, than occurred in the absence of Dex (Table 2). The presence of Dex in the medium did not cause a greater increase of the SOD activity/mg protein than was found in tissue incubated without Dex. Dex added to the assay buffer in a concentration of $10 \mathrm{nM}$ did not by itself affect the rate of reduction of ferricytochrome $c$. Therefore the changes observed by us in the presence of Dex reflect a true effect of this compound on the lung enzyme. Assays performed on the culture medium showed that no significant amounts of enzyme were released by the explants under the conditions studied.

$\mathrm{Cu}, \mathrm{Zn}$ SOD and general protein turnover. The rate of general protein synthesis $(18.9 \pm 1.8 \mathrm{nmol}$ Phe incorporated $/ \mathrm{mg}$ DNA/ h) (Table 3) in the absence of Dex is similar to the rate of protein synthesis found in lung slices studied immediately after killing 20- to 22-day-old fetuses or 2- to 3-day-old neonates (Hass M, Massaro D, unpublished data). The rate of general protein synthesis and of the synthesis of $\mathrm{Cu}, \mathrm{Zn}$ SOD were both decreased about $50 \%$ in the presence of Dex (Table 3). The rate of general 


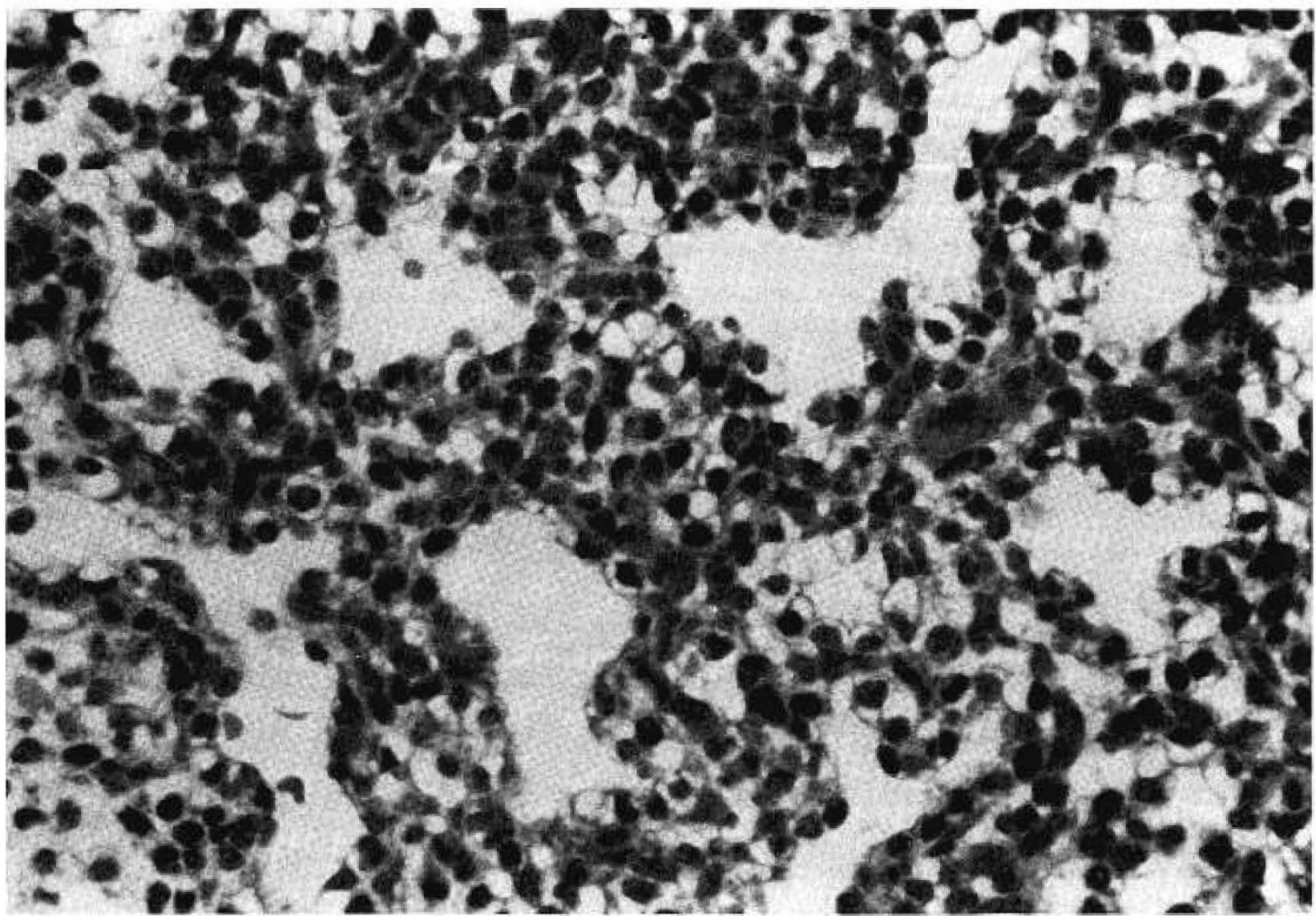

Fig. 1. Histological appearance of lung explant maintained in serum free Waymouth $752 / 1$ medium for $72 \mathrm{~h}$ in a gas phase of $95 \% \mathrm{O}_{2}-5 \% \mathrm{CO}_{2}$. Haematoxylin and eosin, $\times 320$.

Table 1. Protein and DNA content* of fetal rat lung organ cultures maintained for $72 \mathrm{~h}$

\begin{tabular}{lccc}
\hline & “0” $\mathrm{H}$ & $\begin{array}{c}72 \mathrm{H}: \\
\text { no Dex }\end{array}$ & $\begin{array}{c}72 \mathrm{H}: \\
10 \mathrm{~nm} \text { Dex }\end{array}$ \\
\hline Protein $(\mu \mathrm{g} / \mathrm{mg}$ wet wt) & $32 \pm 2.0$ & $35 \pm 2.7$ & $45 \pm 4.5$ \\
DNA $(\mu \mathrm{g} / \mathrm{mg}$ wet wt $)$ & $12 \pm 0.6$ & $10 \pm 0.3$ & $11 \pm 1.5$ \\
Protein/DNA ratio & $2.6 \pm 0.2$ & $3.4 \pm 0.3$ & $4.0 \pm 0.3 \dagger$ \\
\hline
\end{tabular}

* Data reported as mean $\pm \mathrm{SE}(n=11)$. Values for protein content reflect the soluble $800 \mathrm{~g}$ supernatant fraction.

$\dagger p<0.05$ with respect to " 0 " $\mathrm{h}$ value.

protein degradation was also decreased in tissue exposed to Dex $(-75 \%)$. The rate of degradation of $\mathrm{Cu}, \mathrm{Zn}$ SOD was small but detectable in explants incubated without Dex (Table 3). We could not detect degradation of the enzyme during the incubation period used in explants incubated with Dex.

\section{DISCUSSION}

The major results of the present study are that there is a spontaneous increase of SOD activity in fetal lung explants cultured under hyperoxic conditions in serum-free medium, and this increase is greater in the presence of Dex. Since $1 \mathrm{~mm}^{3}$ explants of lung tissue in organ culture undergo necrosis in other than a hyperoxic environment (5) we could not perform experiments at a $\mathrm{PO}_{2}$ that simulates the $\mathrm{O}_{2}$ to which the fetal lung is exposed in vivo. Therefore, we could not determine if the sponraneous increase of SOD activity reflects continued developmental maturation in culture, as is seen in vivo, or is an adaptive response to hyperoxia. However, the in vitro increase of SOD activity in rat lung explants over $72 \mathrm{~h}$ (1.9-fold) is about the same as noted in vivo over $72 \mathrm{~h}$ in the fetal rabbit (1). This similarity, although in different species, suggests the in vitro increase of SOD activity may represent, at least in part, normal biochemical development of the lung's antioxidant enzyme system. The additional in vitro increase of SOD activity we found in serum-free Dex-treated explants shows the lung can directly respond to Dex. This finding does not establish that the in vivo effect of Dex to increase SOD activity also represents a direct action of Dex on the lung, but the similarity of the magnitude of the in vivo and in vitro response to Dex suggests this is the case (4).

Previous attempts to demonstrate time-dependent increases in SOD activity, in vitro, under serum-free conditions have been unsuccessful. Autor et al. (12) and Frank et al. (13) found no change in SOD activity in lung slices kept in air though the incubation period lasted only $6 \mathrm{~h}$. An increase in enzyme activity in response to hyperoxia occurred only when incubations were carried out in rat plasma or whole blood. More recently Tanswell and Freeman (14) using a differentiation arrested primary monolayer mixed cell culture from rat fetal day 20,22 or postnatal day 3 rat lungs, were unable to show any spontaneous increase in SOD activity with time in an ambient atmosphere of $5 \% \mathrm{CO}_{2}$ in air. Furthermore there was no response to acute hyperoxic challenge with $50 \% \mathrm{O}_{2}$ for up to $48 \mathrm{~h}$, in the presence of $10 \%$ bovine fetal calf serum. In the absence of serum fetal day 20 tissue exposed to hyperoxia showed an increase in SOD activity associated with cell damage and release of $\mathrm{LDH}$ in the medium (14).

The mechanisms responsible for the in vitro increase of SOD activity observed in organ culture have been partly elucidated by our turnover experiments. Since the rate of $\mathrm{Cu}, \mathrm{Zn}$ SOD synthesis is clearly greater than that of $\mathrm{Cu}, \mathrm{Zn}$ SOD degradation, the spontaneously increasing SOD activity seen in the explants over 


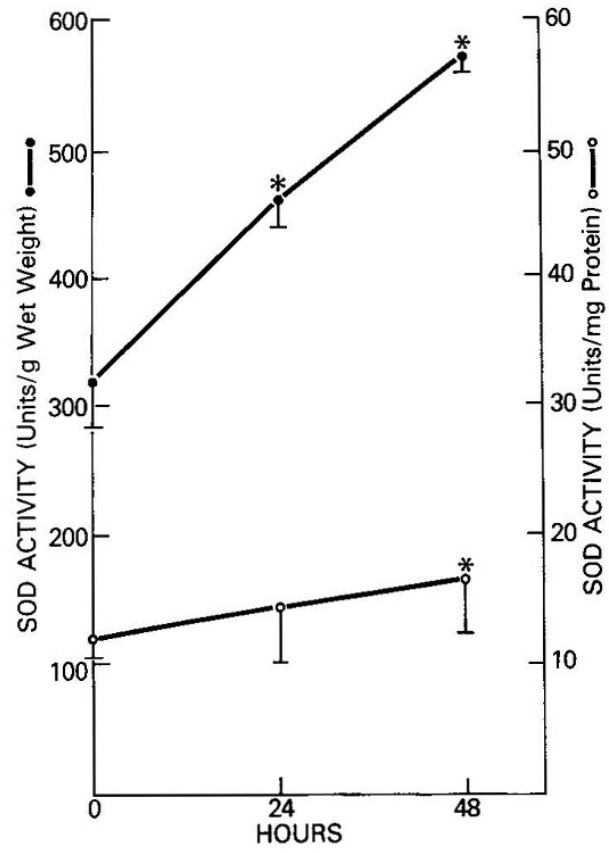

Fig. 2. Sequential rise in SOD activity in serum-free fetal rat lung organ cultures over $48 \mathrm{~h}$. Enzyme activity is expressed as U/g wet weight $(--)$ ) or as $\mathrm{U} / \mathrm{mg}$ protein $\left(\mathrm{O}_{-}-\mathrm{O}\right)$. Each point represents mean \pm SEM $(n=6)$. The asterisk indicates values significantly higher than the $0 \mathrm{~h}$ values; $(p<0.05)$.

Table 2. Effect of 10 nM Dex on SOD activity* in fetal rat lung organ cultures

\begin{tabular}{lccc}
\hline & & $72 \mathrm{H}:$ & $72 \mathrm{H}:$ \\
& "0" H & no Dex & $10 \mathrm{~nm} \mathrm{Dex}$ \\
\hline SOD U/g wet wt & $240 \pm 15$ & $360 \pm 21 \dagger$ & $470 \pm 58 \dagger \ddagger$ \\
SOD U/mg protein & $7.8 \pm 0.9$ & $10.9 \pm 1.0 \dagger$ & $10.2 \pm 1.9$ \\
SOD U/mg DNA & $17.5 \pm 3.1$ & $33.5 \pm 6.2 \dagger$ & $40.1 \pm 9.3 \dagger \ddagger$ \\
\hline
\end{tabular}

* Data expressed as mean $\pm \mathrm{SE}(n=11)$.

$\dagger p<0.05$ relative to " 0 " $\mathrm{h}$ value.

$\ddagger p<0.05$ relative to " $72 \mathrm{~h}$ : no Dex" values.

Table 3. Cu,Zn SOD and protein turnover in fetal rat lung organ cultures*

\begin{tabular}{|c|c|c|c|}
\hline & Control & Dex & $\begin{array}{c}\text { Paired } \\
t \text { test } \\
\text { control } v s \text { Dex }\end{array}$ \\
\hline $\begin{array}{l}\text { Rate of protein synthesis } \dagger \\
\quad(n=7)\end{array}$ & $18.9 \pm 1.8$ & $8.5 \pm 0.8$ & $p<0.001$ \\
\hline $\begin{array}{l}\text { Rate of protein degradation } \dagger \\
\quad(n=4)\end{array}$ & $3.3 \pm 1.0$ & $0.8 \pm 0.5$ & $p<0.01$ \\
\hline $\begin{array}{l}\text { Rate of } \mathrm{Cu}, \mathrm{Zn} \text { SOD synthe- } \\
\quad \text { sis } \dagger(n=7)\end{array}$ & $13.5 \pm 3.4$ & $7.2 \pm 1.6$ & $p<0.05$ \\
\hline $\begin{array}{l}\text { Rate of } \mathrm{Cu}, \mathrm{Zn} \text { SOD degrada- } \\
\text { tion } \dagger(n=4)\end{array}$ & $0.9 \pm 1.2$ & $1.03 \pm 0.4) \ddagger$ & NS \\
\hline
\end{tabular}

* Data expressed as mean \pm SE. NS $=p>0.05$.

$\dagger$ Synthesis rates of proteins are expressed in $\mathrm{nm}$ Phe incorporated/ $\mathrm{mg} \mathrm{DNA} / \mathrm{h}$. Protein degradation rates reflect Phe release from protein, expressed as nm per mg DNA per $h$. For $\mathrm{Cu}, \mathrm{Zn}$ SOD the values are in pmol rather than nanomoles.

$\$$ The negative sign is used to indicate a slight increase in $\mathrm{Cu}, \mathrm{Zn}$ SOD associated Phe content seen during the period of observation.
$72 \mathrm{~h}$, reflects, at least in part, an actual increase in the amount of enzyme protein due to a rate of synthesis that exceeds the rate of enzyme breakdown. The action of Dex on the synthesis of $\mathrm{Cu}, \mathrm{Zn}$ SOD suggests Dex acts to increase the enzyme activity by causing a decrease in the degradation of the enzyme that is out of proportion to the inhibitory effect of Dex on the synthesis of $\mathrm{Cu}, \mathrm{Zn} \mathrm{SOD}$. The degradation rates observed by us are consistent with such a view: Dex treated explants, unlike the controls, showed no decrease in $\mathrm{Cu}, \mathrm{Zn}$ SOD associated label over the 24$\mathrm{h}$ period studied. However, the differences in the rates of $\mathrm{Cu}, \mathrm{Zn}$ SOD degradation between control and Dex-treated explants were not significant when measured over a period of $24 \mathrm{~h}$. In view of the slow turnover of $\mathrm{Cu}, \mathrm{Zn}$ SOD in organ culture, it would have been necessary to extend the degradation study over a period of several days to obtain numerical values for the half-life of the enzyme under culture conditions. The onset of unfavorable histological changes in the explants after $72 \mathrm{~h}$ in culture precluded us from carrying out such studies. It is also possible to explain the data obtained by us by mechanisms other than a Dex-induced effect on the rate of enzyme degradation: increased total SOD activity in the Dex-treated explants, in face of a decreased rate of synthesis of $\mathrm{Cu}, \mathrm{Zn}$ SOD, could reflect an opposite effect of Dex on the copper-zinc and manganese forms of SOD, both activities being combined in our measurement of SOD activity. Alternatively, Dex could produce conformational changes in the enzyme molecule leading to enhanced specific activity per mol of $\mathrm{Cu}, \mathrm{Zn} \mathrm{SOD}$ protein. We have evidence that enzyme activation of this sort takes place in vivo during normal development (Hass M, Massaro D, unpublished observations).

Acknowledgment. The authors thank Mrs. Ondina GarciaPons for assistance in preparing the manuscript.

\section{REFERENCES}

1. Frank L, Groseclose EE 1984 Preparation for birth into an $\mathrm{O}_{2}$-rich environment: the antioxidant enzymes in the developing rabbit lung. Pediatr Res 18:240-244

2. Tanswell AK, Freeman BA 1984 Pulmonary antioxidant enzyme maturation in the fetal and neonatal rat. I. Developmental profiles. Pediatr Res 18:584587

3. Gerdin E, Tyden O, Eriksson UJ 1985 The development of antioxidant enzymatic defense in the perinatal rat lung: activities of superoxide dismutase, glutathione peroxidase and catalase. Pediatr Res 19:687-691

4. Frank L, Lewis PL, Sosenko IRS 1985 Dexamethasone stimulation of rat lung antioxidant enzyme activity in parallel with surfactant stimulation. Pediatrics 75:569-574

5. Gross I, Walker Smith GJ, Maniscalco WM, Czajka MR, Wilson CM, Rooney SA 1978 An organ culture model for study of biochemical development of fetal rat lung. J Appl Physiol 45:355-362

6. McCord JM, Fridovich I 1969 Superoxide dismutase, an enzymatic function for erythrocuprein (hemocuprein). J Biol Chem 244:6049-6055

7. Bradford M $1976 \mathrm{~A}$ rapid and sensitive method for the quantitation of microgram quantities of protein utilizing the principle of protein dye binding. Anal Biochem 71:248-254

8. Hill BT, Whatley S 1975 A simple rapid microassay for DNA. FEBS Lett $56: 20-23$

9. Schneider WC 1951 Determination of nucleic acids in tissue by pentose analysis. Methods Enzymol 3:680-684

10. Hass MA, Frank L, Massaro D 1982 The effect of bacterial endotoxin on synthesis of $\mathrm{Cu}, \mathrm{Zn}$ superoxide dismutase in lungs of oxygen exposed rats. $\mathrm{J}$ Biol Chem 257:9379-9383

11. Chiang M-J, Whitney P, Massaro D 1979 Protein metabolism in lung: use of isolated perfused lung to study protein degradation. J Appl Physiol 47:7278

12. Autor AP, Frank L, Roberts RJ 1976 Developmental characteristics of pulmonary superoxide dismutase: relationship to idiopathic respiratory distress syndrome. Pediatr Res 10:154-158

13. Frank L, Bucher J, Roberts RJ 1978 Oxygen toxicity in neonatal and adult animals of various species. J Appl Physiol 45:699-704

14. Tanswell AK, Freeman BA 1984 Differentiation arrested rat fetal lung in primary monolayer cell culture. III. Antioxidant enzyme activity. Exp Lung Res 6:149-158 